\title{
Delayed mouth-caecum transit of a lactulose labelled liquid test meal in patients with steatorrhoea caused by partially treated coeliac disease
}

\author{
R C SPILLER, Y C LEE, C EDGE, D N L RALPHS, J S STEWART, \\ $S$ R BLOOM, AND D B A SILK
}

From the Department of Gastroenterology and Nutrition, Central Middlesex Hospital, London, Department of Medicine, Royal Postgraduate Medical School, Hammersmith Hospital, London, Department of Surgical Studies, Middlesex Hospital, London, and West Middlesex Hospital, Isleworth, Middlesex

Summary Mouth-caecum transit time (M-CTT) of a lactulose labelled liquid test meal has been measured in 27 coeliac patients and 10 healthy controls using the breath hydrogen technique. Although all patients were urged to maintain a gluten free diet, not all did, and there was, therefore, a wide range in the severity of fat malabsorption within the patient group. Gastric emptying of a ${ }^{1 ! 3}$ Indium DTPA-labelled liquid test meal was also assessed in separate studies on six healthy controls and 11 of the coeliac patients. Fasting breath hydrogen concentrations and the response to lactulose, as assessed both by the rate of rise, and the peak breath hydrogen concentration reached, showed no difference between coeliacs and controls, regardless of the presence or absence of steatorrhoea. Mouth-caecum transit time in the 16 coeliac patients with steatorrhea (faecal fat $>7 \mathrm{~g} / 24 \mathrm{~h}$ ) was, however, significantly prolonged being $158 \pm 18$ minutes (mean \pm SEM), compared with $70 \pm 9$ minutes for the controls $(\mathrm{p}<0 \cdot 02)$, and $83 \pm 15$ minutes for the 11 coeliacs without steatorrhoea $(\mathrm{p}<0 \cdot(0) 2)$. Mouth-caecum transit time in the coeliac patients was linearly related to the 24 hour faecal fat excretion, $r=0 \cdot 55, n=27, p<0 \cdot 01$. Slow mouth-caecum transit in the coeliacs with steatorrhoea was not caused by delayed gastric emptying as the $t_{1 / 2}$ for coeliacs with steatorrhoea was within the normal range. Coeliacs with delayed mouth-caecum transit had impaired insulin release but the postprandial profiles of the other peptides measured (cholecystokinin, GIP, secretin, motilin, neurotensin, enteroglucagon, and peptide YY) were all within the normal range in this group of partially treated coeliac patients.

Although coeliac patients with fat malabsorption may have frequent loose and bulky stools, paradoxically such patients often have an abnormally slow mouth-caecum transit ${ }^{1-3}$ as assessed radiologically. Direct manometric studies have shown that the sluggish intestinal movements and dilated loops of bowel noted radiologically, are associated with reduced pressure wave activity. ${ }^{+5}$ The cause of this hypomotile state is unknown, but our recently published findings" suggest that unabsorbed fat entering the ileum can inhibit jejunal motor activity while simultaneously releasing a number of 'ileal' Address for correspondence: Dr R C Spiller. Department of Gastrocenterology
and Nutrition. Central Middlesex Hospital. I ondon. NW10 7NS.

Received for publication 19 February. 1987. regulatory peptides. The aim of this study was to further investigate the relationship between fat malabsorption, small bowel transit and the release of regulatory peptides in a group of coeliac patients who were maintaining a gluten free diet with varying degrees of strictness.

\section{Methods}

SUBJECTS

Mouth-caecum transit of a lactulose labelled liquid test meal was assessed using the breath hydrogen technique in 32 coeliac patients and 14 controls, while blood samples were drawn simultaneously for measurement of the postprandial gut hormone 
response. The ileal exposure to fat was estimated by measuring the 24 hour faecal fat excretion during the week before the test day and, in 11 of the coeliacs and six healthy controls, gastric emptying of a liquid, lactulose labelled test meal was assessed shortly afterwards. All subjects gave their informed consent and all studies had prior approval of the Brent District Ethical Committee (30 September, 1982).

Thirty two coeliacs, 16 men and 16 women, aged 18-77 years (mean 48.5) took part in this study. All had had a diagnosis of coeliac disease made by jejunal biopsy and had experienced marked clinical, biochemical, and haematological improvement on starting a gluten free diet as shown in appendix A. This response had been confirmed by improvement of villous morphology on repeat jejunal biopsy in all but two of the patients who had refused repeat biopsy. Since performing this study in 1982 all but two of the patients have continued to attend for regular follow up by both dietitians and physicians. Adherence to the prescribed gluten free diet was assessed at the time of the study from a dietary history by two experienced dietitians who graded dietary lapses from $0-3$ as follows; $0=$ no lapses apparent, $1=$ occassional lapses but $<1 \times$ per month, $2=$ frequent lapses $>1 \times$ per month but $<2 \times$ per week, and $3=>2 \times$ per week, often daily lapses owing to failure to understand the diet. Sixteen of the patients still had steatorrhoea at the time of study (patients 12-27 appendix A), of these, six were judged by the dietitian to show poor compliance with the prescribed diet and nine of the 15 who underwent repeat jejunal biopsy continued to show severe or moderate partial villous atrophy. The two patients with faecal fats $>50 \mathrm{~g} / 24 \mathrm{~h}$ have been further investigated with pancreatic function tests and barium small bowel studies without identifying any other cause for malabsorption. Their slow response to the gluten free diet may have been partly because of their age at diagnosis (59 and 62 years) which tends to slow response to gluten withdrawal.?

Eleven of the 32 coeliac patients taking part in this study also had their gastic emptying assessed. These 11 were selected so that six had slow M-CTT (range 115-250) and five had fast transit times (range 33-81 minutes).

Controls were recruited from medical and nursing staff, five men and nine women who were free from known past or present gastrointestinal complaints with a normal frequency of defecation $(<3 \times$ per day and $>3 \times$ per week). Haemoglobin, red cell folate, serum $B_{12}$, albumin, calcium and routine liver function tests were all within the normal range. The age of these controls was 18-42 years (mean $32 \cdot 5$ ) which was not significantly different from our coeliac group of 18-77 years (mean age $48 \cdot 5$ ).
MOUTH-CAECUM TRANSIT TIME MEASUREMENT Subjects were asked to avoid beans, lentils, peas and root vegetables the day before the study. Subsequently, after an overnight fast, at 900 am subjects ingested $200 \mathrm{ml}$ of the enteral feed Clinifeed 4()() (Rousell Laboratories Ltd, London) to which had been added $16.5 \mathrm{~g}$ of the non-absorbable disaccharide, Lactulose $(25 \mathrm{ml}$ Duphalac syrup, Duphar Laboratories Ltd, Southampton). They then ate a slice of gluten free toast (Aproten, Plada SPA, Italy), drank $200 \mathrm{ml}$ black coffee (Nescafé Gold Blend, The Nestlé Company Ltd, Croydon) and in order to avoid excessive distension they then waited 30 minutes before drinking a further $175 \mathrm{ml}$ Clinifeed with $25 \mathrm{ml}$ water. The total meal volume was $6(0) \mathrm{ml}$ and contained $65 \mathrm{~g}$ carbohydrate, $24 \mathrm{~g}$ protein and $14 \mathrm{~g}$ fat, providing $1.8 \mathrm{MJ}(430 \mathrm{kcal})$. Both parts of the meal had an osmolality of approximately 395 mosmol $/ \mathrm{kg}$. Breath hydrogen was measured using a hydrogen sensitive polarographic cell (Exhaled Hydrogen Monitor, GMI, Renfrew, Scotland) to analyse $50 \mathrm{ml}$ samples of end expiratory breath collected at 10 minute intervals using a modified Haldane-Priestly tube. ${ }^{x}$ After a slight rise occurring at about 20 minutes, the breath hydrogen concentration normally fell and remained steady for a variable time after which it then rose steadily, producing an approximately sigmoid curve. The time to the first sustained rise (more than 10 parts per million (ppm) above basal) in breath hydrogen concentration was taken to represent the transit time of the head of the meal (M-CTT). Curves were only considered interpretable if (a) the basal values were less than $20 \mathrm{ppm}$ and (b) the rise in breath hydrogen was sustained for more than 30 minutes. Satisfactory breath hydrogen curves were obtained in 27 of the 32 coeliacs and 10 of the 14 controls, the remaining curves were uninterpretable either because of high basal values (four controls and four coeliacs) or because breath hydrogen failed to show a sustained rise (one coeliac). The rate of rise of the breath hydrogen was assessed in $\mathrm{ppm} / \mathrm{minute}$ from the slope of the curve lying between 10 and $50 \%$ of the maximal rise in breath hydrogen.

Venous blood samples (at times $0,30,60,120,180$, and 240 minutes) were taken through an indwelling cannula into chilled Heparinised tubes containing $200 \mu \mathrm{l}$ of the protease inhibitor, Aprotinin (Trasylol, Bayer, W. Germany). Plasma was then rapidly separated by centrifugation at $4^{\circ} \mathrm{C}$ and stored at $-20^{\circ} \mathrm{C}$ before the assay for 'gut hormones'.

GASTRIC EMPTYING

After an overnight fast, 11 of the coeliacs and six healthy volunteers ingested $300 \mathrm{ml}$ of an homogenised solution containing $200 \mathrm{ml}$ Clinifeed $400,25 \mathrm{ml}$ 
lactulose syrup, and $75 \mathrm{ml}$ water labelled with $1 \mathrm{mCi}$ of Indium ${ }^{113 m}$ DTPA (diethylamine-, triamine-, penta acetic acid). Subjects were then seated reclining at $45^{\circ}$ in front of a gamma camera (Nuclear Enterprises, Model NE8900) which was set to detect the $390 \mathrm{KeV}$ photopeak of the ${ }^{113 m}$ Indium. Counts were recorded for 60 consecutive one minute intervals and stored in a Varian Minicomputer. At subsequent playback, counts were corrected for decay and then expressed as per cent of the initial maximum within the gastric area. The very short half life of "In (1.7 hours) minimises the radiation dose, which has been estimated to be $<0 \cdot 8$ rads per study.

\section{ASSAYS}

Twenty four hour faecal fat excretion was assessed by analysis of a single stool using the standard Van der Kamer method." Subjects ingested eight radioopaque pellets three times daily for five days while on a $100 \mathrm{~g}$ fat diet, and the 24 hour faecal fat excretion was estimated from the fat content of the single stool times $24 / n$ where $n$ equals the number of pellets counted on radiography of the stool. Plasma concentrations of insulin and the gut hormones GIP, ", CCK (cholecystokinin), ${ }^{12}$ secretin, ${ }^{13}{ }^{2}$ motilin, ${ }^{14}$ NT (neurotensin), ${ }^{15}$ EG (enteroglucagon), ${ }^{16}$ and PYY (peptide YY) ${ }^{17}$ were measured using previously described radioimmunoassays. The $95 \%$ confidence detection limits were as follows: (all pmol/l) Insulin $4 \cdot 0$, GIP $3 \cdot 0$, CCK $1 \cdot 0$, secretin $1 \cdot 0$, motilin $5 \cdot 0$, NT 5.0, EG 6.0 and PYY 2.0. Intra- and interassay variability as assessed by the coefficient of variation of repeated measures were as follows; Insulin 1.0 and 2.3; GIP 9.3 and 12.0; CCK $12 \cdot 0$ and $15 \cdot 1$; secretin 6.0 and 13.0; motilin 5.0 and 12.0; NT 5.6 and 14.0; EG 6.7 and 19.3; and PYY 9.0 and $15.0 \%$ respectively.

\section{STATISTICAL ANALYSIS}

Results in the test are expressed as mean \pm standard error of mean. As both the M-CTT and faecal fat values showed a non-normal skewed distribution the significance of differences between groups was assessed using the nonparametric Mann-Whitney $U$ test and the correlation between values assessed by the Spearman rank correlation coefficient.

\section{Results}

\section{BREATH HYDROGEN PROFILES}

Despite some simple dietary restrictions, fasting breath hydrogen concentrations varied widely in both coeliacs and controls (Table 1). Hydrogen production by the coeliac patients in response to lactulose was not different from controls as assessed both by the rate of rise and by the peak levels of
Table 1 Breath hydrogen profiles (mean $\pm S E M$ )

\begin{tabular}{|c|c|c|c|c|}
\hline & $n$ & $\begin{array}{l}\text { Fasting } \\
\text { ppm }\end{array}$ & $\begin{array}{l}\text { Peak } \\
\text { ppm }\end{array}$ & $\begin{array}{l}\text { Rate of rise } \\
\mathrm{ppm} / \mathrm{min}\end{array}$ \\
\hline Controls & 14 & $\begin{array}{l}28 \cdot 4(3-125) \\
\pm 9 \cdot 2\end{array}$ & $\begin{array}{l}89 \cdot 4(39-133) \\
\pm 1(0.5\end{array}$ & $\begin{array}{l}1 \cdot 0 \\
\pm 0 \cdot 3\end{array}$ \\
\hline All coeliacs & 32 & $\begin{array}{l}17 \cdot 0(0-60) \\
\pm 3 \cdot 4\end{array}$ & $\begin{array}{l}87 \cdot 5(32-180) \\
\pm 9 \cdot 8\end{array}$ & $\begin{array}{l}2 \cdot 0 \\
\pm 0 \cdot 8\end{array}$ \\
\hline $\begin{array}{l}\text { Cocliacs with } \\
\text { steatorrhoca } \\
>14 \mathrm{~g} / 24 \mathrm{~h}\end{array}$ & 10 & $\begin{array}{l}21 \cdot 8(0-60) \\
\pm 6 \cdot 7\end{array}$ & $\begin{array}{l}78 \cdot 5(33-160) \\
\pm 17 \cdot 3\end{array}$ & $\begin{array}{l}2 \cdot 2 \\
\pm 1 \cdot 3\end{array}$ \\
\hline $\begin{array}{l}\text { Cocliacs } \\
\text { without } \\
\text { stcatorrhoea } \\
<7 \mathrm{~g} / 24 \mathrm{~h}\end{array}$ & 11 & $\begin{array}{l}10 \cdot 8(0-37) \\
\pm 3 \cdot 2\end{array}$ & $\begin{array}{l}96 \cdot 2(32-180) \\
\pm 14 \cdot 2\end{array}$ & $\begin{array}{l}1 \cdot 9 \\
\pm 0 \cdot 6\end{array}$ \\
\hline
\end{tabular}

Ranges shown in parentheses. No significant difference between controls and either of patient groups.

postprandial breath hydrogen. Furthermore, even when only those coeliacs with moderate to marked steatorrhoea $(>14 \mathrm{~g} / 24 \mathrm{~h})$ were considered, these likewise appeared to respond to lactulose in the same way as controls. Thus fat malabsorption did not appear to alter the metabolism of lactulose in a significant manner.

\section{MOUTH-CAECUM TRANSIT TIMES}

As a group, coeliacs had a very wide range of M-CTT (Fig. 1) so that the group mean, 124 \pm 14 minutes

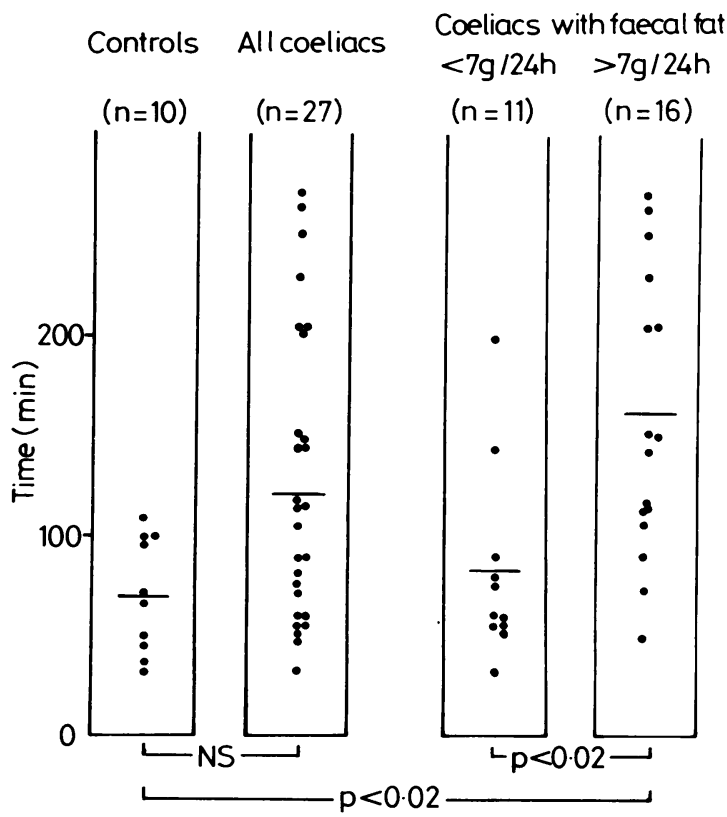

Fig. 1 Chart on left shows mouth-caecum transit time (min) for controls compared with all ceoliac patients, the chart on the right shows M-CTT in the coeliac patients divided into those with or without steatorrhoea. 


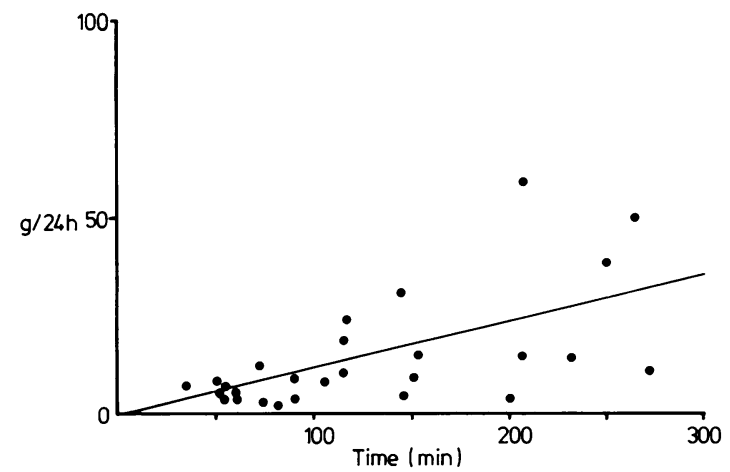

Fig. 2 Correlation between faecal fat ( $\mathrm{g} / 24 \mathrm{~h})$ and mouthcaecum transit time (min) for all coeliac patients $(n=27$, $r=0.55, p<0 \cdot 01$ ).

$(\mathrm{n}=27)$, did not differ significantly from the control value, $70 \pm 9$ minutes $(n=10)$. When the patients were subdivided into 16 with steatorrhoea (faecal fat $>7 \mathrm{~g} / 24 \mathrm{~h}$ ) and 11 without steatorrhoea, however, those with steatorrhoea had significantly longer transit times (158 \pm 18 minutes) than those without $(83 \pm 15, \mathrm{p}<0.02)$, whose transit times did not differ

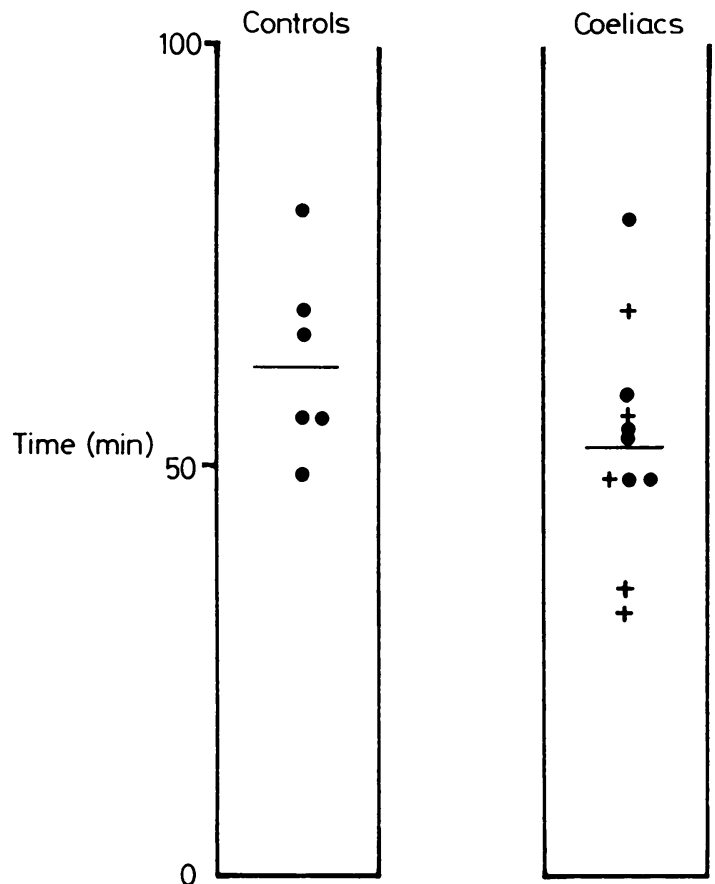

Fig. 3 Time for $50 \%$ gastric emptying for controls $(n=6)$ and coeliac patients $(n=11)$, difference not significant. - indicates values for patients without steatorrhoea, + indicates values for patients with faecal fat excretion $>14 \mathrm{~g} / 24 \mathrm{~h}$. significantly from the healthy controls $(70 \pm 9$ minutes). Furthermore when transit time was plotted against faecal fat (Fig. 2) there was a significant correlation, the Spearman rank correlation coefficient being $(0 \cdot 55, \mathrm{n}=27, \mathrm{p}<0) \cdot 01$.

\section{GASTRIC EMPTYING}

Gastric emptying in the 11 coeliac patients studied was found to be exponential, log counts remaining in the stomach at $10,20,30,40$, and 60 minutes showing a negative linear correlation with time, correlation coefficients ranging from -0.98 to $-0.99(n=5$, $\mathrm{p}<0.001)$. A similar relationship was found with the six controls (correlation coefficients $-(0.83$ to -0.99 , all $\mathrm{p}<0 \cdot 01)$. Using the time for $50 \%$ of isotope to leave the stomach $\left(t_{12}\right)$ as a measure of gastric emptying, there was no difference between controls and coeliacs (Fig. 3) $t_{1 / 2}$ being $61.8 \pm 4.7$ minutes and $52.5 \pm 4.0$ minutes respectively. Considering only the five coeliacs studied with marked steatorrhoea $(>14 \mathrm{~g} / 24 \mathrm{~h}), \mathrm{t}_{\mathrm{I}}$ was $47 \cdot 6 \pm 6 \cdot 6$ minutes, which again was not significantly different from the controls. Thus both qualitatively and quantitatively the gastric emptying of the liquid test meal was similar in coeliacs and controls. As others have found ${ }^{1 \mathrm{x}}$ there was no relationship between the rate of gastric emptying as assessed by $t_{1 / 2}$ and mouth-caecum transit times $(r=-0 \cdot 29, n=11, N S)$.

\section{GUT HORMONE RELEASE (Table 2)}

As expected from previous work, ${ }^{19}$ when compared with controls the release of insulin, GIP, and cholecystokinin tended to be impaired, while the release of 'ileal' peptides - for example, neurotensin, enteroglucagon and peptide YY tended to be increased in coeliacs with more marked steatorrhoea (faecal fat excretion $>14 \mathrm{~g} / 24 \mathrm{~h}$ ). Owing to wide variability in response to the test meal, however, only the insulin and GIP differences reaches statistical significance (Table 2). This impaired insulin and GIP response occurred in the coeliac patients in spite of plasma glucose rises which did not differ from controls.

There was no significant correlation between M-CTT and any of the other hormone responses as assessed by peak level or integrated incremental response (IIR) when all the coeliacs were considered as a group. Furthermore when the hormone responses of the 10 coeliacs with the slowest transit (M-CTT >130 minutes) were compared with the 10 coeliacs with the fastest transit (M-CTT $<80$ minutes) there were no significant differences in either peak levels or the incremental integrated response for any of the hormones studied except for insulin which was significantly lower in those with the slowest transit $(\mathrm{IIR}=16 \cdot 5 \pm 5 \cdot 6, \mathrm{n}=10, v 31 \cdot 6 \pm 3 \cdot 3$ 
Table 2 Guthormone and glucose response to meal

\begin{tabular}{|c|c|c|c|c|c|c|c|c|c|c|c|c|c|c|c|c|c|c|c|}
\hline & \multirow[b]{2}{*}{$n$} & \multicolumn{2}{|c|}{ Insulin } & \multicolumn{2}{|l|}{$G I P$} & \multicolumn{2}{|l|}{$C C K$} & \multicolumn{2}{|c|}{ Secretin } & \multicolumn{2}{|l|}{$N T$} & \multicolumn{2}{|l|}{$E G$} & \multicolumn{2}{|c|}{ Motilin } & \multicolumn{2}{|l|}{$P Y Y$} & \multicolumn{2}{|c|}{ Glucose } \\
\hline & & Peak & $I I R$ & Peak & $I I R$ & Peak & $I I R$ & Peak & $I I R$ & Peak & $I I R$ & Peak & $I I R$ & Peak & $I I R$ & Peak & $I I R$ & Peak & $I I R$ \\
\hline & & & $\times 10^{3}$ & & $\times 10^{3}$ & & $\times 10^{3}$ & & $\times 10^{3}$ & & $\times 10^{3}$ & & $\times 10^{3}$ & & $\times 10^{3}$ & & $\times 10^{3}$ & & $\times 10^{4}$ \\
\hline Controls & 10 & $\begin{array}{l}411 \\
\pm 38\end{array}$ & $\begin{array}{l}43 \cdot 3 \\
\pm 3 \cdot 8\end{array}$ & $\begin{array}{l}65 \\
\pm 7\end{array}$ & $\begin{array}{l}5 \cdot 8 \\
\pm 1 \cdot 2\end{array}$ & $\begin{array}{l}12 \cdot 6 \\
\pm 1.9\end{array}$ & $\begin{array}{l}0.92 \\
\pm 0.6\end{array}$ & $\begin{array}{l}3 \cdot 4 \\
\pm 0 \cdot 3\end{array}$ & $\begin{array}{l}155 \\
\pm 105\end{array}$ & $\begin{array}{l}47 \\
\pm 4\end{array}$ & $\begin{array}{l}1.8 \\
\pm 0.7\end{array}$ & $\begin{array}{l}172 \\
\pm 15\end{array}$ & $\begin{array}{l}14 \cdot 0 \\
\pm 2 \cdot 0\end{array}$ & $\begin{array}{l}34 \\
\pm 4\end{array}$ & $\begin{array}{l}-1.4 \\
\pm 1.0\end{array}$ & $\begin{array}{l}35 \\
\pm 3\end{array}$ & $\begin{array}{l}3 \cdot 3 \\
\pm 0 \cdot 4\end{array}$ & $\begin{array}{l}6 \cdot 3 \\
\pm 0 \cdot 2\end{array}$ & $\begin{array}{l}104 \\
\pm 42\end{array}$ \\
\hline $\begin{array}{l}\text { Cocliacs } \\
\text { Faccal fat } \\
>14 \mathrm{~g}\end{array}$ & 10 & $\begin{array}{l}256^{*} \\
\pm 45\end{array}$ & $\begin{array}{l}11 \cdot 6^{*} \\
\pm 5.4\end{array}$ & $\begin{array}{l}41 \dagger \\
\pm 3\end{array}$ & $\begin{array}{l}3 \cdot 3^{*} \\
\pm 0 \cdot 7\end{array}$ & $\begin{array}{c}9 \cdot 0 \\
\pm 1 \cdot 3\end{array}$ & $\begin{array}{l}0.56 \\
\pm 0.2\end{array}$ & $\begin{array}{l}2 \cdot 7 \\
\pm 0 \cdot 2\end{array}$ & $\begin{array}{c}59 \\
\pm 37\end{array}$ & $\begin{array}{l}52 \\
\pm 9\end{array}$ & $\begin{array}{l}0 \cdot 9 \\
\pm 1 \cdot 0\end{array}$ & $\begin{array}{l}213 \\
\pm 4\end{array}$ & $\begin{array}{l}16 \cdot 0 \\
\pm 4 \cdot 0\end{array}$ & $\begin{array}{l}82 \\
\pm 17\end{array}$ & $\begin{array}{r}0.8 \\
\pm 1.3\end{array}$ & $\begin{array}{l}43 \\
\pm 9\end{array}$ & $\begin{array}{l}3 \cdot 8 \\
\pm 1 \cdot 1\end{array}$ & $\begin{array}{l}6 \cdot 6 \\
\pm 0 \cdot 2\end{array}$ & $\begin{array}{l}104 \\
\pm 49\end{array}$ \\
\hline $\begin{array}{l}\text { Cocliacs } \\
\text { Faccal fat } \\
<7 \mathrm{~g}\end{array}$ & 11 & $\begin{array}{l}282^{*} \\
\pm 37\end{array}$ & $\begin{array}{l}31 \cdot 6 \\
\pm 3 \cdot 3\end{array}$ & $\begin{array}{l}53 \\
\pm 5\end{array}$ & $\begin{array}{l}4 \cdot 8 \\
\pm 0 \cdot 6\end{array}$ & $\begin{array}{l}10 \cdot 3 \\
\pm 1 \cdot 6\end{array}$ & $\begin{array}{l}0 \cdot 6 \\
\pm 0 \cdot 1\end{array}$ & $\begin{array}{l}3 \cdot 1 \\
\pm 0 \cdot 2\end{array}$ & $\begin{array}{c}27 \\
\pm 51\end{array}$ & $\begin{array}{l}39 \\
\pm 7\end{array}$ & $\begin{array}{l}1.9 \\
\pm 0.2\end{array}$ & $\begin{array}{l}147 \\
\pm 21\end{array}$ & $\begin{array}{l}11 \cdot 8 \\
\pm 1 \cdot 1\end{array}$ & $\begin{array}{l}82 \\
\pm 14\end{array}$ & $\begin{array}{l}-0 \cdot 3 \\
\pm 1 \cdot 2\end{array}$ & $\begin{array}{l}31 \\
\pm 3\end{array}$ & $\begin{array}{l}3 \cdot 3 \\
\pm 0 \cdot 2\end{array}$ & $\begin{array}{l}7 \cdot 0 \\
\pm 0 \cdot 5\end{array}$ & $\begin{array}{l}138 \\
\pm 50\end{array}$ \\
\hline
\end{tabular}

${ }^{*}$ Difference from controls $\mathrm{p}<0 .(0)$; †difference from controls $\mathrm{p}<0 .() 2$. IIR=integrated incremental response over four hours, all values $\mathrm{pmol} / \mathrm{l}$. min; Peak = peak posprandial levels all pmol/l except glucose mmol/l.

nmol/l.min, $\mathrm{n}=10, \mathrm{p}<() \cdot(05)$. Gut hormone release did not correlate with gastric emptying with the exception of peptide YY, whose peak levels were inversely correlated with the $t_{1 / 2}$ for gastric emptying $(\mathrm{r}=0 \cdot 68, \mathrm{n}=11, \mathrm{p}<0 \cdot 05)$.

\section{Discussion}

We have shown, using a sensitive, non-invasive technique, that as a group coeliacs with fat malabsorption tend to show a delayed mouth-caecum transit in spite of apparently normal gastric emptying. Although the breath hydrogen technique for assessing M-CTT has been extensively validated in normal subjects ${ }^{2121}$ this has not been done before in coeliacs. The present study has found no difference between coeliacs and controls in the breath hydrogen response to lactulose, as assessed both by the rate of rise and by the peak levels attained. This suggests that once lactulose reaches the caecum it is metabolised in the normal way, and therefore the breath hydrogen method should give reliable results in this condition. Our finding that there was no impairment of hydrogen production in steatorrhoea was of particular importance in excluding the possibility that the correlation between M-CTT and faecal fat was an artefact of the measurement technique. The slightly higher average age of our patients raises the possibility that age per se may cause delayed transit, however we found no correlation between age and transit time, $\mathrm{r}=0 \cdot 28, \mathrm{n}=27, \mathrm{p}>0 \cdot 10$, in agreement with others..$^{22}$

This finding of slow small bowel transit in a disease characterised by diarrhoea and fast mouth to anus transit seems initially paradoxical. Colonic transit normally accounts for the major part of mouth to anus transit, however, and it seems likely that although mouth to caecum transit is delayed, colonic transit is accelerated in steatorrhoea, although this has yet to be proved in man. A possible mechanism for such an acceleration has been provided by recent experimental studies which have indicated that in normal man, long chain fatty acids infused into the caecum accelerate colonic transit. ${ }^{23}$ Extrapolation from normal subjects to patients with malabsorption, however, may not justified and further studies of colonic function in coeliac patients are obviously needed to answer this point.

Defective absorption, or net secretion of water and electrolytes in the coeliac jejunum would be predicted to increase the volume of small bowel contents and, in the absence of other effects, this should produce an acceleration of transit, as is seen in healthy controls when net water secretion is induced by successively larger doses of lactulose..$^{24}$ Our finding of a delay in small bowel transit implies therefore the existence of some inhibitory mechanism in coeliacs with steatorrhoea.

The gastric emptying of our mainly liquid meal was exponential, both coeliacs and controls showing similar emptying profiles. These studies make it unlikely that delayed gastric emptying was a cause of the slow mouth-caecum transit observed. Other authors $^{25}$ have noted a tendency for coeliacs with steatorrhoea to have slightly faster gastric emptying than controls. Although we did note abnormally fast gastric emptying in two patients (Fig. 3) who had marked steatorrhoea (faecal fat 18.4 and $58.8 \mathrm{~g} / 24 \mathrm{~h}$ ), as a group, patients with steatorrhoea $>14 \mathrm{~g} / 24 \mathrm{~h}$ did not differ significantly from controls in this respect.

Gastric emptying did not appear to influence gut hormone response significantly, with the exception of PYY, whose release was inversely proportional to the $t_{1 / 2}$ of gastric emptying. This recently described ${ }^{26}$ regulatory peptide is known to exert inhibitory effects on gastric secretion ${ }^{27}$ and emptying. ${ }^{28}$ Our finding, that its release correlated inversely with gastric $t_{1 / 2}$, encourages us to speculate that there is a 
feedback control mechanism whereby rapid gastric emptying, in the presence of fat malabsorption, leads to the release of PYY which may inhibit further delivery of nutrients from the stomach to the small bowel. Unfortunately precise quantitative comparison between our mouth to caecum studies and the gastric emptying is not possible as the meals, although isocaloric and identical in nutrient composition, were not of the same volume. This was necessitated because not all patients were able to consume the $400 \mathrm{ml}$ comprising the first part of the original test meal fast enough $(<60 \mathrm{sec})$ as required for the gastric emptying studies. We therefore choose to reduce the volume to $300 \mathrm{ml}$ which was consumed by all patients within the required time. This difference, however, does not invalidate the conclusion that there is no evidence that patients with prolonged M-CTT have delayed gastric emptying which therefore implies that the main delay in mouth to caecum transit occurred in the small bowel.

The failure of some of our patients' jejunal biopsies to return to normal in spite of treatment appears most likely to be because of failure to maintain a strict gluten free diet. The subsequent four year follow up has not revealed any alternative diagnoses, in particular no patients have developed small bowel lymphoma or other complications of coeliac disease. Of the nine patients with steatorrhoea $>14 \mathrm{~g} / 24 \mathrm{~h}$ none had normal villous architecture on repeat jejunal biopsy. Two of the patients were eating gluten containing foods $>2 \times$ per week and only two were considered to have a satisfactory diet: One of these two was studied after only three months on the diet which may explain the incomplete response. As already mentioned the two with severe steatorrhoea were in their 6th decade at the time of diagnosis, an additional factor other than poor diet compliance, which may explain their persisting villous damage. Other causes of severe steatorrhoea such as pancreatic insufficiency and small bowel contamination were excluded in the two patients with faecal fats $>50 \mathrm{~g} / 24 \mathrm{~h}$ by means of a Lund test meal and aerobic and anaerobic cultures of jejunal fluid apirated before giving the Lund meal.

The hormonal response to our test meal differed somewhat from that previously reported by Besterman et $a l^{19}$ from the same laboratory. Although the trend for coeliacs with steatorrhoea to have impaired release of secretin and GIP with increased release of neurotensin and enteroglucagon was still found the differences were less striking and did not reach statistical signficance. This is almost certainly because of the fact that our patients were all partially treated while Besterman's active coeliac group were all studied before treatment. A further factor tending to blurr the differences between coeliacs and controls was the fact that our liquid meal contained the osmotic cathartic lactulose which is known to induce a degree of nutrient malabsorption..$^{9}$ We assessed this aspect in separate studies in which we intubated six healthy volunteers with a 175 $\mathrm{cm}$ multilumen tube and infused intragastrically over 10 minutes the same test meal used in our mouthcaecum transit study. We found that substantial amounts of glucose could be detected $(41 \cdot 0) \pm 15 \cdot 4$ $\mathrm{mmol} / \mathrm{l})$ in the two hour postprandial period in intestinal aspirates $175 \mathrm{~cm}$ from the mouth, representing absorption of only $78 \cdot 2 \pm 7 \cdot 1 \%$ of meal carbohydrate. This is considerably less than previously reported ${ }^{\text {in }}$ after similar liquid test meals not containing lactulose and may explain why our normal controls exhibited such marked rises in neurotensin and enteroglucagon both of which can be released by glucose.

Mouth to caecum transit is obviously influenced by

Appendix A Patient details before and after gluten-free die'

\begin{tabular}{|c|c|c|c|c|c|c|c|c|c|}
\hline No & $H \mid b l$ & $R \cdot f l$ & lfat & Jejhx & $\mathrm{Hb} \mathrm{I}$ & 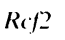 & Ifoll? & $J_{e j h}$ & Die't \\
\hline 1 & $11 \cdot 6$ & 180 & $23 \cdot 11$ & SVA & $1.3 \cdot 0$ & 148 & 2.5 & NAD & () \\
\hline 2 & $12 \cdot 7$ & 105 & $12 \cdot 10$ & SVA & $12 \cdot 0$ & 235 & 3.0 & NAD & () \\
\hline 3 & $16 \cdot 2$ & 107 & 10.5 & SVA & $16 \cdot 3$ & 308 & 3.9 & NAD) & 0 \\
\hline 4 & 12.9 & 74 & $25 \cdot 1)$ & SPVA & $14 \cdot 2$ & 170 & $4 \cdot 1$ & NAD & () \\
\hline 5 & $14 \cdot 3$ & 165 & 7.9 & SVA & $1.3 \cdot 4$ & 471 & $4 \cdot 1$ & mPVA & () \\
\hline 6 & $10 \cdot 6$ & 180 & $34 \cdot 2$ & SVA & $1.3 \cdot 3$ & 450 & $4 \cdot 3$ & NAI) & () \\
\hline 7 & $8 \cdot 4$ & 96 & $26 \cdot 3$ & SVA & $14 \cdot 3$ & 186 & 5.0 & mPVA & () \\
\hline 8 & 11.8 & 53 & $27 \cdot(1)$ & SVA & $12 \cdot 4$ & 55 & $5 \cdot 0$ & PVA & 1 \\
\hline 9 & 13.9 & 112 & NA & SVA & $1.3 \cdot 1$ & 776 & 5.9 & mPVA & () \\
\hline 10) & 10.7 & 68 & 13.0 & SVA & $13 \cdot 2$ & 306 & 6.7 & PVA & 1 \\
\hline 11 & $12 \cdot 2$ & 78 & $21 \cdot 0$ & SVA & $12 \cdot 3$ & 294 & $6 \cdot 8$ & ND & () \\
\hline 12 & 10.9 & 97 & NA & SVA & $12 \cdot 3$ & 282 & 7.9 & mPVA & 0 \\
\hline 13 & 14.5 & 198 & $26 \cdot 0$ & SVA & 15.9 & 408 & $8 \cdot 7$ & mPVA & 0 \\
\hline 14 & $15 \cdot 7$ & 73 & $17 \cdot 0$ & SVA & $16 \cdot 3$ & 182 & $9 \cdot(1)$ & PVA & () \\
\hline 15 & $13 \cdot 7$ & 1.32 & $6 \cdot 1$ & SVA & $15 \cdot 3$ & 209 & $9 \cdot 4$ & PVA & 1 \\
\hline 16 & $4 \cdot 8$ & 20 & $24 \cdot()$ & PVA & 12.7 & 220 & 10.7 & NAD & 0 \\
\hline 17 & $11 \cdot 3$ & 114 & $4 \cdot 3$ & SVA & $13 \cdot 2$ & 94 & $11 \cdot 0$ & ND & 2 \\
\hline 18 & $4 \cdot 0$ & 74 & $5 \cdot 1$ & SVA & 14.5 & 1.37 & $12 \cdot 7$ & NAD & 2 \\
\hline 19 & $9 \cdot 6$ & 35 & $34 \cdot 6$ & SVA & $12 \cdot 4$ & 74 & $14 \cdot 3$ & sPVA & 3 \\
\hline 20) & $16 \cdot 1$ & 65 & $45 \cdot 0$ & SVA & $15 \cdot 7$ & 153 & $15 \cdot 1$ & mPVA & () \\
\hline 21 & 12.9 & 100 & 34.9 & SVA & $12 \cdot 3$ & 898 & $15 \cdot 1$ & PVA & 1 \\
\hline 22 & $11 \cdot 0$ & 76 & NA & SVA & 13.3 & 70 & 18.4 & PVA & 1 \\
\hline 23 & $12 \cdot 0$ & 32 & $10 \cdot 0$ & SVA & 14.7 & 145 & $24 \cdot 0$ & SPVA & 3 \\
\hline 24 & $13 \cdot 1$ & 70 & $71 \cdot 1)$ & SVA & 13.8 & 450 & $31 \cdot 1$ & SPVA & () \\
\hline 25 & $9 \cdot()$ & 135 & $31 \cdot 0$ & SVA & 11.7 & 199 & $39 \cdot 4$ & mPVA & 0 \\
\hline 26 & 11.4 & 40 & $19 \cdot 0$ & SVA & $12 \cdot 8$ & 108 & $51 \cdot 1$ & PVA & 2 \\
\hline 27 & $13 \cdot 3$ & 78 & $45 \cdot 5$ & SVA & $14 \cdot 4$ & 248 & $58 \cdot 8$ & sPVA & 2 \\
\hline
\end{tabular}

$\mathrm{H} \mathrm{b}=$ hacmoglobin $\mathrm{g} / \mathrm{dl}: \mathrm{Rcf}=\mathrm{red}$ cell folate $\mathrm{ng} / \mathrm{ml} ; \mathrm{Ffat}=$ faccal fat $\mathrm{g} / 24 \mathrm{~h} . \mathrm{NA}=$ result not available; $J \mathrm{Jcjbx}=$ jejunal hiopsy. $\mathrm{SVA}=$ subtotal villous atrophy - that is, absent villi usually with crypt hyperplasia; PVA = partial villous at rophy - that is, a degree of villous stunting graded mild, moderate and severe and indicated by the initials mPVA, PVA, and SPVA respectively, NAD = within normal imits; $\mathrm{ND}=$ repeat biopsy not yet done; $\mathrm{Dict}=$ dictary lapses scored from 0-3 according to criteria given in the text dealing with subject details. Values followed by the number 1 are all pretreatment while values followed by 2 are those obtained at the time of study, which was in all cases post treatment. 
many factors but considering just the variables we assessed - that is, gastric emptying, gut hormone release and faecal fat, the best predictor of delayed M-CTT was the 24 hour faecal fat excretion which accounted for $30.3 \%$ of the variance in M-CTT. This relationship could be spurious, as the faecal fat excretion is itself an indicator of severity of the mucosal lesion and would be expected to correlate with many other features of coeliac disease. Alternatively it could be that the presence of fat in the terminal ileum and colon is per se responsible for an inhibitory influence on jejunal motility as we $\mathrm{e}^{\mathrm{f}}$ and others" have shown experimentally in healthy subjects. Whatever the precise mechanism this effect accounts only in part for the delayed transit observed, and there are obviously other important factors both hormonal and neural which control small bowel transit. Nevertheless we believe that this delay in transit may be important because the increased mucosal contact time, particularly in the relatively undamaged ileum, may allow increased absorption in partially treated coeliac patients.

We would like to thank Dr M Shiner for allowing us to include some of her patients in our study. This work has been presented in abstract form at the 1984 Spring meeting of the British Society of Gastroenterology held in Salford.

\section{References}

I Snell AM, Camp JD. Chronic idiopathic steatorrhoearoentenologic observations. Ann Intern Med 1934; 53: 615-29.

2 Perman G, Mattson $O$. The small intestine transit time in steatorrhoca. Acat Med Scand 1962; 171: 273-81.

3 Pirk F. Changes in motility of the small intestine in digestive disorders. Gut 1967; 8: 486-90.

4 Ingelfinger FJ, Moss RE. The motility of the small intestine in sprue. $J$ Clin Invest $1943 ; 22: 345-52$.

5 Ritchie JA, Salem SN. Upper intestinal motility in ulcerative colitis, idiopathic steatorrhoea, and the irritable bowel syndrome. Gut 1965; 6: 325-37.

6 Spiller RC, Trotman IF, Higgins BE, et al. The ileal brake - inhibition of jejunal motility after ileal fat perfusion in man. Gut 1984; 25 : 365-74.

7 Pena AS. Truelove SC, Whitehead R. Disaccharidase activity and jejunal morphology in coeliac disease. $Q J$ Med 1972: 41: 457-76.

8 Metz G, Gassull MA, Leeds AR. Blendis LM. Jenkins DJA. A simple method of measuring breath hydrogen in carbohydrate malabsorption by end-expiratory sampling. Clin Sci Mol Med 1976; 50: 237-40.

9 Heading RC. Tothill P, Laidiaw AJ. Shearman DJC. An evaluation of "I:m Indium DTPA chelate in the measurement of gastric emptying by scintiscanning. Gut 1971; 12: $611-5$.

10 Henry RJ, Cannon DC, Winkelman JW. Clinical chemistry. New York: Harper \& Row, 1974: 1481-3.
11 Sarson DL. Bryant MG. Bloom SR. A radioimmunoassay of gastric inhibitory polypeptide in human plasma. $J$ Endocrinol 198(); 85: 487-96.

12 Ghateri MA. Jung RT, Stevenson JC, et al. Bombesin: action on gut hormones and calcium in man. $J$ Clin Endocrinol Metab 1982; 54: 980-5.

13 Greenberg GR. Secretin. In: Bloom SR, Long RG, eds. Radioimmunoassay of gut regulatory peptides. London: WB Saunders, 1982.

14 Bloom SR, Mitznegg P. Bryant MG. Measurement of human plasma motilin. Scand J Gastroenterol 1976; 11 : suppl 39: 47-52.

15 Blackburn AM, Bloom SR. A radioimmunoassay for neurotensin in human plasma. $J$ Endocrinol 1979; 83: $175-81$.

16 Ghatei MA. Uttenthal LO, Christofides ND, Bryant MG, Bloom SR. Molecular forms of human enteroglucagon in tissue and plasma: plasma responses to nutrient stimuli in health and in disorders of the upper gastrointestinal tract. J Clin Endocrinol Metab 1983; 57: $488-95$.

17 Adrian TE, Ferri G-L, Bacarese-Hamilton AJ, Fuessi HS, Polak JM, Bloom SR. Human distribution and release of a putative new gut hormone. Peptide YY. Gastroenterology 1985; 89: 1070-7.

18 Read NW. Cammack J, Edwards C. Holgate Am, Cann PA, Brown C. Is the transit time of a meal through the small intestine related to the rate at which it leaves the stomach. Gut 1982; 23: 824-8.

19 Besterman HS, Sarson DL, Johnson DI, et al. Gut hormone profile in coeliac disease. Lancet 1978; i: $78.5-8$.

20 Bond JH, Levitt MD. Investigation of small bowel transit time in man utilising pulmonary hydrogen $\left(\mathrm{H}_{2}\right)$ measurements. J Lab Clin Med 1975; 85: 546-55.

21 Caride VJ. Prokop EK, Troncale FJ, Buddoura W, Winchenback K. McCallum RW. Scintigraphic determination of small-intestinal transit time: comparison with the hydrogen breath technique. Gastroenterology 1984; 86: $714-20$.

22 Feibusch JM, Holt PR. Impaired absorption capacity for carbohydrate in the ageing human. Dig Dis Sci 1982; 27: 1095-100.

23 Spiller RC, Brown ML, Phillips SE. Decreased fluid tolerance, accelerated transit and abnormal motility of the human colon induced by oleic acid. Gastroenterology 1986; 91: 100-7.

24 Read NW, Miles CA. Fisher D, et al. Transit of a meal through the stomach, small intestine and colon in normal subjects and its role in the pathogenesis of diarrhoea. Gastroenterology 1980; 79: 1276-82.

25 Moberg S. Carlberger G. Gastric emptying in healthy subjects and in patients with various malabsorptive states. Scand J Gastroenterol 1974; 9: 17-21.

26 Tatemoto K. Mutt V. Isolation of two novel candidate hormones using a chemical method for finding naturally occurring polypeptides. Nature $1980 ; 285$ : 417-8.

27 Adrian TE, Sagor GR, Savage AP. et al. Low dose PYY inhibits gastric secretion in man. [Abstract]. Gut 1983; 24: A479.

28 Allen JM. Fitzpatrick ML. Yeats JC, Darcy K, Adrian TE, Bloom SR. Effect of peptide YY and neuropeptide 
$\mathrm{Y}$ on gastric emptying in man. Digestion 1984; 30: 225-62.

29 Holgate AM. Read NW. Relationship between small bowel transit time and absorption of a solid meal. Influence of metoclopramide, magnesium sulphate, and lactulose. Dig Dis Sci 1983; 28: 812-19.

30 Borgstrom B, Dahlqvist A. Lundh G, Sjovall J. Studies of intestinal digestion and absorption in the human. $J$ ( Clin Invest 1957: 36: 1521-36.

31 Read NW. McFarlane A. Kinsman RI. at al. Effect of infusion of nutrient solutions into the ileum on gastrointestinal transit and plasma levels of neurotensin and enterglucagon. Gastrochterology 1984: 86: 274-80. 